\title{
THE USE OF SIMPLE PRESENT TENSE AND ADJECTIVES ON STUDENTS' DESCRIPTIVE WRITING AT PRIVATE VOCATIONAL SCHOOL IN BOGOR
}

\author{
Arif Triyuono ${ }^{1}$, \\ Supeno ${ }^{2}$, \\ English Education Program, Postgraduate Faculty \\ Universitas Indraprasta PGRI, Jakarta \\ e-mail: triyuonoarif@ yahoo.com ${ }^{1}$ \\ e-mail: supeno@unindra.ac.id ${ }^{2}$
}

\begin{abstract}
The research objective is to analyze the use of Simple Present Tense and Adjectives on students' Descriptive Writing at Private Vocational School in Bogor. The method used in this study is Descriptive text analysis using qualitative data. The procedures are conducted by choosing the text from students' Descriptive writing, analyzing data, interpreting data, and concluding the result of the study. The result shows that 1) there are common errors produced using simple present tense in descriptive writing. The total error is 239 errors which the highest frequency is misformation error which consists of 128 errors or 54\%. 2) the total error of using Adjectives in Descriptive writing is 25 errors, and the highest frequency of error is misformation which consists of 17 errors or 68\%. The findings in this research are for students' analysis of using Simple Present Tense and Adjectives on Descriptive writing. It occurs because of some reasons they are affected by both Interlingual and Intralingual Error.
\end{abstract}

Keywords: simple present tense; adjectives; descriptive writing

\section{Introduction}

Nowadays, we are facing a new era in our life. This era is known as the digital era. The fast growth of digital-based technology marks it. It gives many implications to our life, for example, the change of people's lifestyle. We are charged to prepare our generations to be ready to deal with facing this new era. The next generations must have good skills and competencies related to the need of this new era.

The skill mastered by them is not only a complex skill but also a soft skill. Hard skill is teachable abilities or skill sets that are easy to quantify and measure. Examples of this kind of skill are typing speed, machine operation, computer programming. On the other hand, soft skill is interpersonal skills used to describe your approach to life, work, and relationships with other people. Kinds of skills related to this kind of skill include communication, leadership, work ethic, creative problem-solving. Our generation must master one soft skill that is communication skills. It is essential because people worldwide are closely connected in the digital era, and the purpose of communication is to give and get information. In the digital era, the flow of information is so fast. It means that if we have good communicative competence, it will be easier for us to receive and know the update of the information.

Communication is an essential component of our life because of communication. We can deliver and receive messages, ideas, thoughts, and other information from other people in the world. When talking about communication, it can be separated from language. Language is the essence of communication because it is the primary tool. Human language is very dynamic and always grows following the era. In daily life, people use language as the medium to deliver their thought and socialized with others. It can be said that language becomes a basic need for every people.

As a medium of communication, language has a critical role. The people who have good ability in language automatically their communicative skill will also be good. Considering the importance of having excellent communicative skills for our generation, the government of Indonesia has put English in the curriculum. In the Indonesian curriculum, English is taught from the elementary up to high education 


\section{INFERENCE: Journal of English Language Teaching}

Vol. 4, No. 2, August-November 2021

p-ISSN: 2615-8671

e-ISSN: 2615-868X

level. It intends that our generation will be accustomed to using English. So they are expected to have good ability in speaking English after graduating from their study, and they will be ready to face the development of an era. English is an international language that is enabled for all people in the world connected. In the globalization era, English becomes a need. It can be seen from many companies that use their employee to be able to communicate in English. From that case, we can say that having communication skills in English is very important, especially for job seekers. It can be an added value for them to be accepted by the company as we know that English significantly dominates in whole aspects of communication. We can see this in most of the communication devices using English. Most advanced countries are Asia using English as a medium of instruction or making it the second language after its language.

Referring to the explanation above, mastering English is very important for every country. However, English is different from Indonesian. English is more complex in structure and pattern. In Indonesian, there is no change in using verbs in any adverb of time. It is different from English which has different verb based on the time we say. For example, the use of a verb in the sentence of present and past condition. These are the examples, in present condition, "I go to school" and in past condition, it will be "I went to school yesterday." From those examples, we can see the different use of verbs that have the same meaning when we translate to Indonesian; they are "go" and "went," which mean "pergi." That is why English is quite challenging to learn for people who have different forms of mother tongue.

Both English and Indonesian have four primary skills. The composition of those four skills started from listening, speaking, reading, and the last is writing. It is taken from the process of human language acquisition, and the learning process of English refers to it. People are getting their first language from what they heard from their environment. After hearing some words from their parents, they try to imitate by saying an unmistakable voice. Then they try to speak syllable by syllable, word by word, until a more complex form of a sentence. When they have had good ability in speaking, they continue to read started with a simple, familiar word. Moreover, the last skill is writing. In this research, the writer decides to choose writing as the object to be observed.

Writing is a process of discovering thoughts, feelings, and opinions about something or someone and organizing them into a suitable arrangement on paper. In addition, it has the function of entertaining and communicating information to others. Considering the function above, it is essential to make our writing easy to understand. This is supported by the statement of Ploeger $(1999$, p. 1), who stated that "Writing is discovering what you know and feel about something, and writing is communicating that knowledge to audience."

For people who learn English, writing becomes the most challenging skill because of the writing process. We will face many difficulties in transferring thoughts and ideas in written form. It is supported by Wingersky et al. (2008, p. 3), who said that "Writing is a process through which you discover, organize, and communicate your thoughts to the reader." According to this opinion, we can say that writing is a process; it can be meant that we have to follow the step-by-step writing process.

According to the explanation above, the teaching-learning process focuses on writing itself. It focuses on constructing an exemplary writing arrangement as we know that writing is a process, not a product. For example, when the English teacher teaches about descriptive writing, he explains the generic structure of a descriptive text and gives the example of descriptive text, and explains the process of making a descriptive text so that the students will be able to make their descriptive text.

To make students motivated and enjoyable in learning English especially writing, the teacher should use interesting methods in teaching so the students will not feel bored. In language learning, they need more models and practice than instruction from their teacher. Therefore, it becomes a challenge for the teacher to motivate the students to practice their English.

According to the curriculum, there are four kinds of writing taught in vocational high school: recount, procedure, narrative, and descriptive. One of the genre texts taught in vocational high school is descriptive text. It is taught by the teacher to make students know how to describe something and someone. It is aimed to make the readers feel as accurate as possible about the information given by the writer. In the descriptive text, there are some language features. The first feature is a specific participant. It means that a descriptive text must have a particular object like name, place, thing, or someone. The second feature is the use of the adjective. It is needed to clarify the noun such as beautiful beach, handsome boy. The third feature is the use of simple present tense as we know that descriptive text tells 
about the truth and object described - the ability of the student in writing descriptive depends on the competence of mastering those kinds of language features. For example, the students who have good competence in simple present and mastering the kinds of adjectives will produce good descriptive text.

The quality of a descriptive text is significantly affected by mastering the simple present tense and adjective. The student research found some difficulties in constructing the descriptive text- those difficulties caused by less ability of simple present and lack of mastering the adjectives. Simple present used to tells about the truth, and it is different with Indonesian there are some changes of verbs depends on the form and the subject of the sentence. Those factors made the students feel difficult to make a descriptive text.

During the process of writing descriptive text, the students sometimes make a mistake even an error. Some factors can cause it. Those factors come either from internal or external. From an internal factor, it may be caused by less understanding of writing and the language features. External factors may be caused by the methods or techniques used by the teacher is not proper with the material.

The writer is interested in focusing on the student's writing descriptive text on verb and adjectives because many students have difficulties putting a proper verb on simple present tense and adjectives writing descriptive text because of the explanation above the writer interested in conducting a research study at SMK Trople J Citeureup and SMK Plus PGRI Cibinong by presenting the use of the simple present tense and adjectives on student's descriptive writing on the tenth-grade students.

Formulation of the Problems: How to use simple present tense and adjectives in students' descriptive writing at private vocational schools in Bogor? Furthermore, What causes errors made by the students in Using simple present tense and adjectives in students' descriptive writing at private vocational schools in Bogor? The objectives of the research are to know: The use of simple present tense and adjectives in students' descriptive writing at private vocational schools in Bogor and The causes of errors made by the students in The use of the simple present tense and adjectives in students' descriptive writing at private vocational schools in Bogor.

\section{Method}

The research was conducted at two Private Vocational High Schools in Kabupaten Bogor: (1) the first school is SMK Plus PGRI Cibinong, located at Jl. Cikaret, Cibinong, Bogor; (2) the second school is SMK Triple J, located at Jl. Nanbau Citeureup. The research activities were applied to the tenth-grade students at the academic year of 2019/2020. The writer chooses those schools because the location of those two schools is near the place of the writer in the same area, Cibinong, and both are private vocational schools.

This research uses the descriptive qualitative method with content analysis. As stated by Drisko \& Mashi (2016, p. 7) who defined that "Content analysis is a family of research technique for making systematic, credible or valid, and replicable inferences from texts and other forms of communication." In qualitative research, the researcher tends to prior an accurate explanation to analyze and present what has been found.

The instrument takes on an important role in the research. It is one of the most critical elements in research because we can get the data from it. Ariola (2006, p. 82) stated, "the research instruments or tools are ways of gathering data." It can be meant that without the instruments, it is impossible to obtain data of research. The instruments to be used is must be appropriate to the study, valid, and also reliable. In this qualitative research, the main instrument is the researcher itself. Here the researcher has a central role in deciding the source of data and how data is collected, analyzed, interpreted, and concluded.

In this research, the writer uses the test as the other research instrument. The test used in this research is to find out the students' skills in writing. The instrument of this research is obtained from the result of descriptive text made by the students. After obtaining the works of descriptive text made by the student, then the writer evaluates them. The evaluation focuses on analyzing the error of the sentence by using simple present tense verbs and adjectives and giving correction and improvement for the students. In composing the descriptive text, the topic will be given by the writer. The writing test that students will make is guided writing. Here the writer instructs how to construct the descriptive text. It is needed in order for the works of the students will be qualified. 
Before providing the worksheet for the students, the writer gives some instructions. This instruction is needed in order to make effective and guided writing. Those instructions are: write a descriptive text about the special one in your life, this text consists of a minimum of 15 sentences, and the time allocation is 45 minutes. In addition, for helping in composing the descriptive text, the following questions are helpful:

1. Whom do you want to describe in your text?

2. Why do you choose her/him as the special one in your life?

3. How about her/his personality?

4. Can you tell about her/his activity?

5. Where does she/he live?

6. When was she/he born?

7. How does she/he look like?

8. What is her/his hobby?

9. Why does she/he like to do the hobby?

10. What are her/his likes/dislikes? (Sports, Foods, music, etc.)

11. What is her/his dream?

After the students finish their writing, the writer collects the students' worksheets then analyzes them. In the next step, the writer looks for and finds the error in the descriptive text made by the students. Finally, the writer concludes the last step and reconstructs the wrong sentences into the correct ones. Therefore the writer gives a copy of their works and explains the error they have made to make an excellent descriptive text the next time.

In conducting the research, the researcher performed some procedures to have the result of the research. First, the writer gives the written test to the tenth-grade students of SMK Triple J and SMK Plus PGRI and asks the students to construct the descriptive text based on the instructions; then, he collects the paper test from the students' data. Second, he identifies the errors of the simple present tense verb and adjectives made by the students. Third, he describes and classifies the errors of the tenses related to its kind using Surface Strategy Taxonomy (Dulay et al., 1982), which has four types of errors: Addition, Omission, Misformation, and Misordering. Next, he counts those errors to determine the dominant and less dominant errors made by the students. Last, he describes the data and concludes the result of the research.

Based on the research methodology above, the researcher will analyze the data using a descriptive qualitative technique. Moleong $(2017$, p. 3) said that "qualitative research deals with a kind of research that does not use statistic procedures to analyze the data." Therefore, the steps of analyzing the data can be seen as follow:

1. Preparing the title related to the students' writing.

2. Asking the students to write descriptive text based on the title.

3. Identifying the errors of simple present tense verb and adjective.

4. Making the reconstruction of the error sentence into the correct one.

5. Classifying the errors' type.

6. Counting the number of errors based on its type.

7. Making percentage of each error type in the table and diagram.

8. Describing the error based on the type.

9. Concluding.

10. Giving the copy of the result to the teacher and the students to improve making descriptive text. 


$$
\begin{array}{ll|} 
& P=\frac{X}{n} \times 100 \% \\
& \\
\mathbf{P} & =\text { Percentage } \\
\mathbf{X} & =\text { Amount of the errors } \\
\mathbf{N} & =\text { Total of the errors }
\end{array}
$$

\section{Results and Discussion}

The data were collected from October $15^{\text {th }}$ to November $6^{\text {th, }} 2019$, from the tenth-grade students at Private Vocational School Plus of PGRI Cibinong and Private Vocational School Plus of Triple J Citeureup. The test was given to the students in composing a descriptive text. The test was conducted at a separate time of the school schedule.

The researcher researched one class of each school. The population of the tenth-grade students of both schools is 600 students. The researcher chooses 60 students or $10 \%$ out of 600 students as the sample of the research. It is a total of 60 student's writing from both schools.

These are the data of counting the errors as below:

Table 1

Type and Number of Error in Each Category Encountered by Students on the Use of Simple Present Tense

\begin{tabular}{|c|c|c|}
\hline Type of Error & $\begin{array}{c}\text { Number of } \\
\text { Error }\end{array}$ & Percentage \\
\hline Omission & 70 & $29 \%$ \\
\hline Addition & 20 & $8 \%$ \\
\hline Misformation & 128 & $54 \%$ \\
\hline Misordering & 21 & $9 \%$ \\
\hline TOTAL & $\mathbf{2 3 9}$ & $\mathbf{1 0 0 \%}$ \\
\hline
\end{tabular}

Table 2

Type and Number of Error in Each Category Encountered by Students on the Use of Adjectives

\begin{tabular}{|c|c|c|}
\hline Type of Error & $\begin{array}{c}\text { Number of } \\
\text { Error }\end{array}$ & Percentage \\
\hline Omission & 5 & $20 \%$ \\
\hline Addition & 2 & $8 \%$ \\
\hline Misformation & 17 & $68 \%$ \\
\hline Misordering & 1 & $4 \%$ \\
\hline TOTAL & $\mathbf{2 5}$ & $\mathbf{1 0 0 \%}$ \\
\hline
\end{tabular}

In tabulating the percentage, the writer uses the formula as follows:

$$
p=\frac{n 1}{\sum n} X 100 \%
$$

P: percentage of each error

$\mathrm{n} 1$ : Total of the given error

$\Sigma \quad$ : Total of the whole errors. 


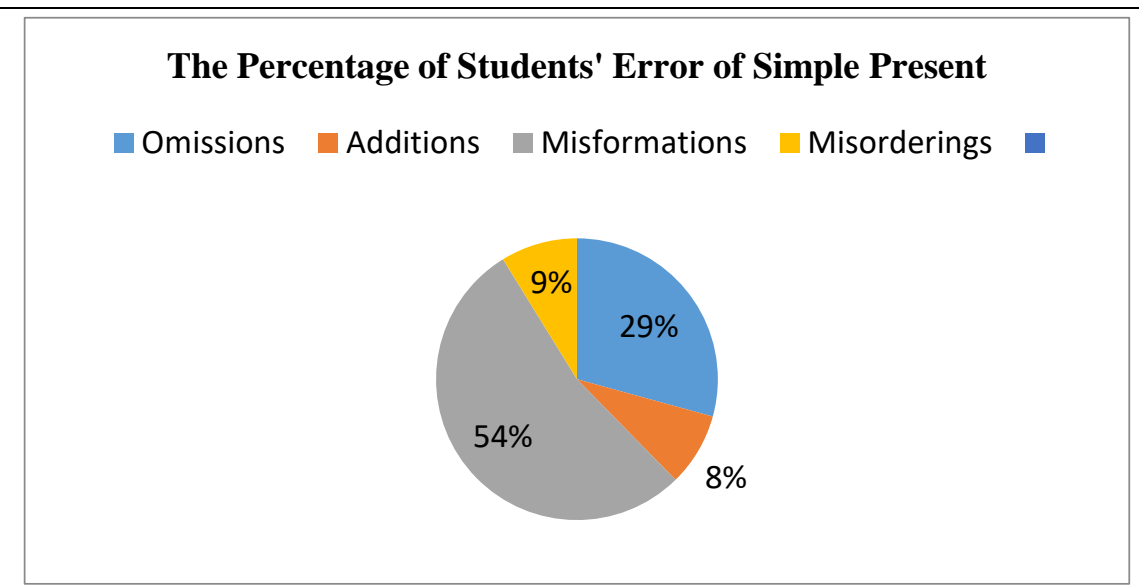

Diagram 1. The Percentage of Students' Error of Simple Present

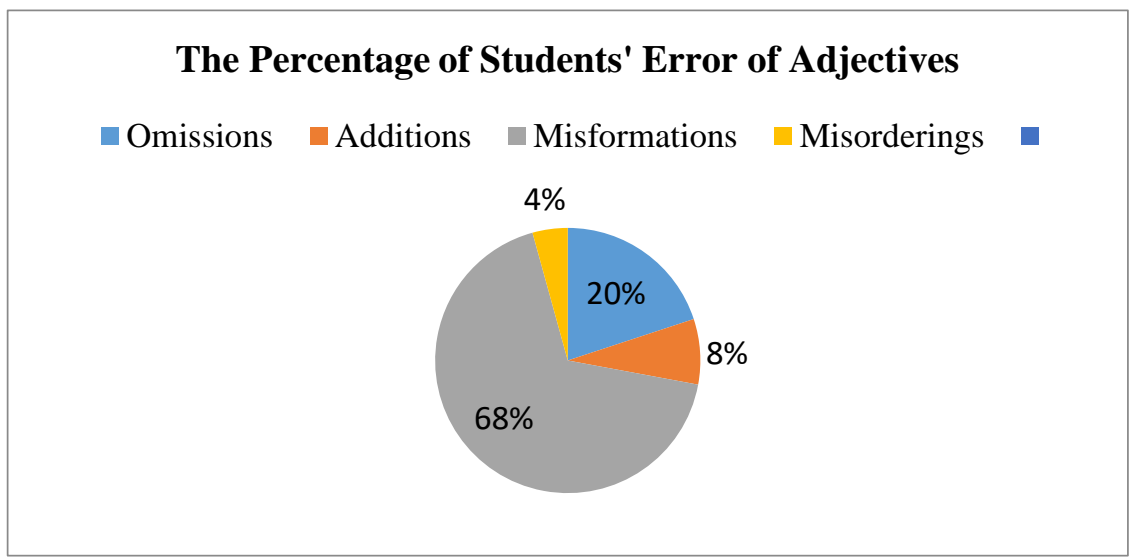

Diagram 2. The Percentage of Students' Error of Adjectives as follow:

Based on the data percentage of error encountered by students, the researcher describes the errors

\section{a. Error of Omission}

Error of omission is the absence of an item that must appear in a well-formed utterance. For example, the students usually omit the suffix "s/es" of a verb in the simple form. Based on the data above, the researcher found that there are 70 or $29 \%$ items out of 239 errors of omission on the use of simple present tense, it is about $13 \%$, and five items out of 25 errors of omission on the use of adjectives, it is about $25 \%$.

\section{b. Error of Addition}

Addition error is the opposite of omission. It is the presence of an item that must not appear in a well-formed utterance. Addition errors happen primarily in using the "to be." The students put it in a sentence that is not needed related to its form. The researcher found that there are 20 items out of 239 errors of addition on the use of simple present tense, it is about 8\%, and two items out of 25 errors of addition on the use of adjectives, it is about $8 \%$.

\section{c. Error of Misformation}

The error of Misformation is characterized by the use of the wrong form of the morpheme. Students could not differ which are regular verb and irregular, which are present tense and past tense, subject and object. In this case, the researcher found 128 items out of 239 errors of misformation on simple present tense, which is about 54\%, and 17 items out of 25 errors of misformation on adjectives are about $68 \%$. 


\section{d. Error of Misordering}

The error of Misordering is incorrect placement of a morpheme or group of morpheme. Sometimes, students make mistakes in choosing the proper word or a group of words, whereas writing the word and word in English and Indonesia is different. In this case, the researcher found that there are 21 items out of 239 errors of misordering on the use of simple present tense, it is about $9 \%$ and 1 item out of 25 errors of misordering on the use of adjectives, it is about $4 \%$.

\section{e. The Causes of Error on the Use of Simple Present Tense and Adjectives}

The dominant error in using simple present tense made by the students is the error of misformation. It is about 54\% which consists of 128 items of error. Furthermore, the less dominant is the error of addition. It is about $8 \%$ which consists of 20 items of error. It occurs because the students are still affected by their mother tongue or first language on target language performance (interlingual). It is the result of language acquisition which is caused by the learner's first language. The students use the pattern of their first language sentence or idiomatic expression in the new language they learn.

On the other hand, this condition is also caused by the lack of understanding of the new language they learn in the learning process (intralingual). As a result, there are some difficulties for the students to know the new language with its aspects. This error may occur when the learner fails to apply the rules entirely in using or applying the language.

\section{Conclusions}

Based on the result, the tenth-grade students of SMK Triple J Citeureup and SMK Plus PGRI Cibinong Bogor made errors in writing descriptive text. The writer found four types of simple present tense error and Adjective's error. The types are omission, addition, misformation, and misordering. The students make some common errors when using the simple present tense in constructing the descriptive text. The total errors are 239 which the highest frequency is misformation error. The misformation error consists of 128 errors or 54\%. The second place is the error of omission, which consists of 70 errors or $29 \%$ - then followed by the error of misordering, which consists of 21 errors or 9\%. Finally, the error is placed to addition which consists of 20 errors or $8 \%$.

From the errors of using simple present tense above, we can see that the students were still confused in arranging sentences related to the correct grammatical function. This is because their first language rule still influenced them in constructing a sentence and the lack of competence in English grammar and vocabularies - the second reason the learning process might cause it.

There are some errors produced in using adjectives in students' descriptive writing. The total errors are 25 errors which the dominant error is misformation error. The misformation error consists of 17 errors or $68 \%$. The second place is the error of omission, which consists of 5 errors or $20 \%$ - then followed by the error of addition which consists of 2 errors or $8 \%$. Finally, the error is placed to misordering, which consists of 1 error or $4 \%$.

From the data above, it can be seen that the students still made some errors in using adjectives in writing descriptive text. Here the students used the wrong form of adjectives. The same with the analysis above, the students still use the Indonesian rule in composing a sentence. They sometimes ignore the grammatical rule of English. It might be caused by the teacher in delivering the material about grammar. The teacher might not use the approach, method, and technique properly, so the material could not be conveyed well.

\section{References}

Ariola, E. A. (2006). Principles and Methods of Research (1st ed.). Rex Book Store. https://books.google.com.ph/books?id=zRY6xxaeyOwC

Drisko, J. W., \& Maschi, T. (2016). Content Analysis. Oxford University Press. https://books.google.co.id/books?id=07GYCgAAQBAJ

Dulay, H. C., Burt, M. K., Krashen, S. D., \& Krashen, S. (1982). Language Two. Oxford University Press. https://books.google.co.id/books?id=FspoAAAAIAAJ

Moleong, L. (2017). Metodologi penelitian kualitatif (28th ed.). Rosda.

Ploeger, K. (1999). Simplified Paragraph Skills. NTC Publishing Group. 
INFERENCE: Journal of English Language Teaching

Vol. 4, No. 2, August-November 2021

p-ISSN: 2615-8671

e-ISSN: $2615-868 \mathrm{X}$

https://books.google.co.id/books?id=RUrNcXMMjzoC

Wingersky, J., Boerner, J. K., \& Holguin-Balogh, D. (2008). Writing Paragraphs and Essays: Integrating Reading, Writing, and Grammar Skills (6th ed.). Cengage Learning.

https://books.google.co.id/books?id=0d0GAAAAQBAJ 